\title{
Piotr Litwa*
}

Uniwersytet Ekonomiczny w Krakowie

\section{POMIAR STOPNIA INNOWACYJNOŚCI PRZEDSIĘBIORSTWA PRZY WYKORZYSTANIU BALANCED SCORECARD}

\begin{abstract}
Streszczenie
Aktualnie przedsiębiorstwa znajdują się pod silną presją innowacji, które są jednym z podstawowych warunków uzyskania przewagi konkurencyjnej. Tylko przedsiębiorstwo zdolne do wprowadzania zmian innowacyjnych może sprawnie i efektywnie funkcjonować na współczesnym rynku. Innowacje dają bowiem szansę zwiększania skali produkcji i sprzedaży, obniżania kosztów czy poprawy jakości wytwarzanych dóbr i usług. Osiągnięcie skuteczności zarządzania innowacjami wymaga ciągłego rozwoju narzędzi decyzyjnych oraz zastosowania się do zasady, że nie można zarządzać tym, co nie jest mierzalne. Z tego powodu celem niniejszego artykułu jest wskazanie możliwości wykorzystania Balanced Scorecard jako kompleksowego narzędzia umożliwiającego pomiar poziomu innowacyjności przedsiębiorstwa.
\end{abstract}

Słowa kluczowe: zrównoważona karta wyników, system pomiaru, innowacyjność

*Adres e-mail: litwap@uek.krakow.pl. 


\section{Wprowadzenie}

Dynamika współczesnego otoczenia gospodarczego sprawia, że powszechnie panuje przekonanie, iż sposobem na sprostanie tym wyzwaniom jest stosowanie innowacyjnych rozwiązań we wszystkich aspektach działalności przedsiębiorstwa. Innowacje te stają się równocześnie źródłem i rezultatem nowatorskiej działalności ludzkiej w zakresie innowacyjności produktów i procesów. W czasach gospodarki opartej na wiedzy innowacyjność staje się zatem determinantą konkurencyjności. Sprawia to, że wiedza i innowacje są podstawowym wyznacznikiem kreującym nową gospodarkę.

Aktualnie można zaobserwować, że czasy bezkrytycznej euforii w podejściu do innowacji, bezpowrotnie minęły i zaczęto uważniej podchodzić do inwestycji w nowe rozwiązania. Wobec tego naturalną tendencją jest żądanie wykazania ich efektywności.

Celem niniejszego artykułu jest zaprezentowanie możliwości wykorzystania koncepcji Balanced Scorecard do pomiaru poziomu innowacyjności przedsiębiorstw.

\section{Istota i znaczenie innowacji}

Pomimo że pojęcie innowacji jest bardzo często omawiane w literaturze ekonomicznej, nie istnieje jednolita definicja tego pojęcia. Wynika to zarówno ze względu na wieloznaczność pojęcia, jak i z powodu trudności z określeniem płaszczyzny porównań jego różnych ujęć. Autorzy zajmujący się tą tematyką prezentują często bardzo różnorodne podejścia do istoty innowacji, jej zakresu oraz skutków.

W sensie ogólnym innowacja pochodzi od łacińskiego słowa innovare oznaczającego odnawianie, wprowadzanie czegoś nowego. W literaturze ekonomicznej pojęcie innowacji zostało wprowadzone przez Josepha Schumpetera, który dostrzegł ekonomiczny wymiar innowacji stosowanych w produkcji, zaopatrzeniu i sprzedaży, określając, że polega ona na wytworzeniu nowego produktu, wdrożeniu nowej metody produkcji, zmianie struktury organizacyjnej czy znalezieniu nowego rynku zbytu. W polskiej literaturze bardzo często prezentowana jest definicja zaproponowana przez Pomykalskiego, który stwierdza, że innowacja jest procesem obejmującym wszystkie działania związane z kreowaniem pomysłu, powstaniem 
wynalazku, a następnie wdrożeniem nowego produktu lub procesu (Pomykalski, 2001, s. 83). Autor ten wyróżnia zasadniczo trzy rodzaje innowacji, przyjmując jako kryterium podziału obszar ich wprowadzenia.

Rysunek 1. Rodzaje innowacji w firmie

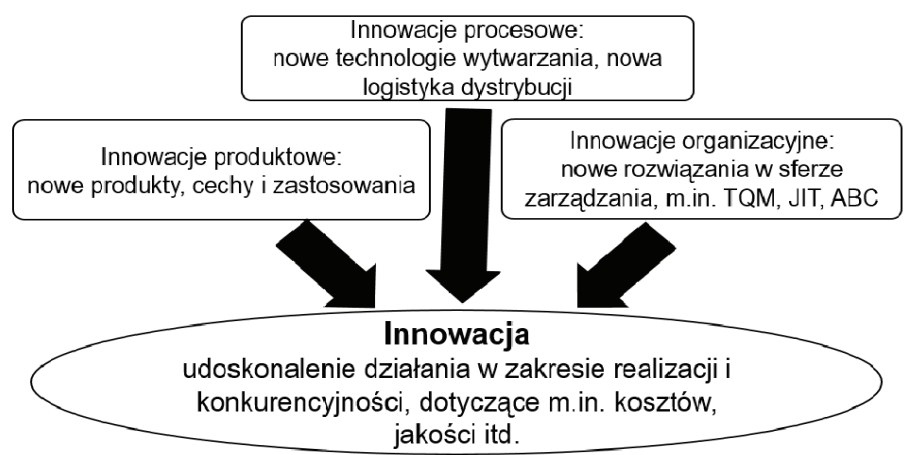

Źródło: Pomykalski (2001), s. 84.

Współcześnie, w dobie gospodarki opartej na wiedzy i informacji, innowacyjność rozumiana jako proces ,uczenia się”, stanowiąca efekt skumulowanej specyficznej wiedzy oraz informacji użytecznej z punktu widzenia przedsiębiorstwa (Matusiak, 2011, s. 54), jest jednym z głównych generatorów przewagi konkurencyjnej podmiotów gospodarczych - zarówno przedsiębiorstw, jak i krajów. Przykładowo Organizacja Współpracy Gospodarczej i Rozwoju (OECD) oraz Eurostat podkreślają zasadniczą rolę tworzenia, wykorzystania i dyfuzji wiedzy dla wzrostu gospodarczego, rozwoju i dobrobytu społeczeństw oraz zwracają uwagę na kluczową funkcję innowacji w tym procesie. Dotyczy to nie tylko innowacji technologicznych w zakresie produktów i procesów (TPP), lecz także innowacji marketingowych i organizacyjnych (OECD i Wspólnoty Europejskie). Według autorów powyższego raportu analiza poziomu i jakości wspomnianych filarów pozwala na określenie źródeł i etapów rozwoju, a także sposobów konkurowania przedsiębiorstw. W tym kontekście warto wspomnieć o trzech najczęściej definiowanych etapach rozwoju oraz modelów konkurowania (Płowiec, 2010):

1. Etapie bazującym na konkurowaniu wysokością cen i użytkowaniu zasobów taniej i nisko wykwalifikowanej siły roboczej oraz surowcach. 
2. Etapie bazującym na konkurowaniu jakością produktów oraz na wysokiej wydajności czynników produkcji osiągniętej dzięki wzrostowi poziomu kwalifikacji pracowników, związanemu z wyższymi płacami oraz wzrostem inwestycji i efektywności.

3. Etapie bazującym na konkurowaniu nowymi i unikatowymi produktami i usługami, powstałymi w wyniku rozwoju innowacyjności.

W publikacji Podręcznik Oslo - Zasady gromadzenia i interpretacji danych dotyczacych innowacji, opracowanym przez Grupę Roboczą OECD Ekspertów Krajowych ds. Wskaźników Naukowo-Technicznych i Grupę Roboczą Eurostatu ds. Statystyki Nauki, Techniki i Innowacji (WPSTI), jak również licznych ekspertów zewnętrznych, zwrócono szczególną uwagę na problemy z pomiarem wkładu i efektów innowacji, gromadzeniem danych oraz konieczność nieustannego rozwijania metodologii pomiaru danych dotyczących innowacji. Trudności wynikają zwłaszcza z tego, że innowacje są procesem o charakterze ciągłym.

\section{Dylematy pomiaru innowacyjności przedsiębiorstw}

Współczesne przedsiębiorstwo powinno być organizacją uczącą się, opartą na wiedzy i aktywnie kreującą jej nowe zasoby. Dlatego organizacja innowacyjna powinna charakteryzować się umiejętnością budowania systemu pozyskiwania, tworzenia i przekazywania wiedzy. Równocześnie musi być również ukierunkowana na przyszłość, antycypować potrzeby klientów, jak również zmiany zachodzące na rynku. W tym celu musi nieustannie poszukiwać nowych rozwiązań, które pozwolą jej na zachowanie konkurencyjności w turbulentnym otoczeniu.

Taka postawa wymaga zdobycia wysoko wykwalifikowanego zespołu odznaczającego się wysokim poziomem kreatywności, który będzie w stanie opracować i wdrożyć nowe koncepcje produktów lub usług o określonych zadawalającym poziomie użyteczności w ocenie klientów. Postępowanie w ten sposób może przynieść przedsiębiorstwu znaczący sukces rynkowy i zapewnić wysoki poziom kreacji wartości, jednak wiąże się też z bardzo wysokim poziomem ryzyka, które wynika w głównej mierze w większości z konieczności poniesienia znacznych nakładów finansowych oraz potencjalnego braku akceptacji produktu przez klientów.

Analizując aktualne doświadczenia najważniejszych przedsiębiorstw na świecie, można z dużym prawdopodobieństwem stwierdzić, że w niedługim czasie 
firmy, które nie będą efektywnie opracowywać i wdrażać rozwiązań innowacyjnych, utracą rację bytu na rynku. Presja rynkowa nie może jednak zwalniać od tego, aby inwestycje w innowacje były oceniane pod względem racjonalności ekonomicznej. Każdorazowa decyzja o podjęciu takich działań powinna być poprzedzona kompleksową oceną poniesionych nakładów i potencjalnych korzyści. Problem oceny poziomu innowacyjności organizacji i wpływu poszczególnych innowacji na działanie, funkcjonowanie i zachowywanie się przedsiębiorstwa jest niezmiernie skomplikowany, co jest zdeterminowane wieloma czynnikami. W tym kontekście w pierwszej kolejności można wskazać na takie czynniki, jak (Brynjolfsson, Yang, 1996):

- niemierzalność kapitału intelektualnego,

- przesunięcie w czasie występujące pomiędzy poniesionymi nakładami a spodziewanymi efektami,

- ryzyko braku akceptacji opracowanych rozwiązań,

- trudności w zarządzaniu.

Problem, jak właściwie ocenić korzyści z inwestycji w innowację, wymaga precyzyjnego zdefiniowania celu tych innowacji oraz zrozumienia wartości, jaką wnoszą one do przedsiębiorstwa. Jest to więc kwestia analogiczna w stosunku do wszelkiego rodzaju inwestycji. W tym miejscu należy zaznaczyć, że sam zysk nie jest właściwą miarą efektywności tego rodzaju inwestycji, co jest uwarunkowane faktem, że zysk jest kształtowany przez wiele rozmaitych czynników, ponadto wiele inwestycji w zakresie innowacyjności ma charakter długookresowy. Właściwą metodą wydaje się wobec tego oparcie się w ocenie nie tylko na wskaźnikach księgowych, lecz także, co może istotniejsze, na systemie mierników niefinansowych.

W tym kontekście należy pamiętać o powszechnym w anglo-amerykańskiej praktyce ekonomicznej podejściu do zarządzania i systemu pomiaru, które opiera się na trzech głównych założeniach (Klingebiel, 1997, s. 658):

- You cannot manage what you cannot measure [nie można zarządzać tym, co nie jest mierzalne].

- What gets measured gets done [tylko to, co jest mierzalne, może zostać wykonane].

- Measurement influences behavior [struktura oraz zakres wskaźników ekonomicznych wpływają na zachowanie pracowników]. 
Podejście takie wydaje się szczególnie trafne w odniesieniu do działalności innowacyjnej przedsiębiorstw. W wypadku inwestycji w innowacyjne rozwiązania absolutnie niezbędne jest precyzyjne i wyraziste określenie zakresu pomiaru oraz jasne sformułowanie celu. Szczególnie istotne jest to zwłaszcza w początkowej fazie procesu wynalazczego, ponieważ innowacyjność jest procesem ciągłym. Przedsiębiorstwa powinny ustawicznie dążyć do wprowadzania zmian w swoich produktach i procesach, jak również nawiązywać nowe relacje biznesowe. Sprawia to, że pomiar tak dynamicznych procesów jest o wiele trudniejszy niż w aktywności statycznej (Kerssens van Drongelen, Bilderbeek, 1999). Z tego powodu kwestia, jak mierzyć poziom i wartość innowacyjności, stała się jednym z podstawowym problemem dla menedżerów i teoretyków ekonomii w ciągu ostatnich dziesięcioleci. Jednak pomimo że w ostatnich latach tematyka pomiaru poziomu innowacyjności w przedsiębiorstwach była przedmiotem wielu publikacji (Neely, 2005), wydaje się, że jest to obszar wciąż słabo zdiagnozowany i opisany. Znajduje to odzwierciedlenie w wielu publikacjach zawierających omówienia problemów i sugerujących możliwość podejścia do pomiaru wydajności, innowacyjności zarządzania obszarem R\&D (Bassani, Lazzarotti, Manzini, Pellegrini, Santomauro, 2010).

\section{Pomiar innowacyjności przy zastosowaniu Balanced Scorecard}

Balanced Scorecard zgodnie z intencją jej twórców, jak wynika to również z empirycznych doświadczeń, stanowi narzędzie umożliwiające realizację misji i strategii przedsiębiorstwa, pozwalające na pogodzenie różnych sprzecznych celów, jakie są stawiane przed organizacjami, oraz eliminujące braki w zakresie realistycznego pomiaru. Jak uściśla David Norton, BSC jest sposobem równoważenia krótkoterminowego myślenia opartego na wynikach finansowych z długoterminowym myśleniem niezbędnym do kreowania przyszłych wyników finansowych. Jak wynika ze słowa „zrównoważony” (balanced), chodzi o równowagę między krótkoi długoterminowym zarządzaniem (Filipek, 2002, s. 9).

Klingebiel stwierdza, że podstawowym celem BSC jest stworzenie systemu zarządzania będącego odzwierciedleniem strategii przedsiębiorstwa, stanowiącego podstawy dla całościowego planowania strategicznego, zarządzania przedsiębiorstwem i kontroli realizacji jego strategii. Motywem przewodnim koncepcji jest integracja w jedną całość zarówno finansowych i niefinansowych celów strategicznych 
i operacyjnych przedsiębiorstwa, jak i procesów planowania z procesami zarządzania (Fink, Grundler, 1998, s. 227). Według innych autorów reprezentujących niemieckie podejście do koncepcji Balanced Scorecard głównym zadaniem BSC jest zespolenie długookresowych celów finansowych z celami strategicznymi przedsiębiorstwa i połączenie w ten sposób tradycyjnego planowania operacyjnego opartego na wskaźnikach finansowych odzwierciedlających rozwój przedsiębiorstwa w przeszłości z planowaniem strategicznym przedsiębiorstwa odnoszącym się do przyszłości. Z kolei w ujęciu anglosaskim, jak twierdzi Weber, strategiczna karta wyników jest odpowiedzią na zorientowane przeważnie na gospodarkę finansową systemy wskaźników. Grupuje wskaźniki w kategoriach finansowych dotyczących klienta, procesów uczenia się (wzrostu) i łączy je na podstawie rzeczowo-logicznych relacji wiążących ich przyczyny ze skutkami. Natomiast Perlitz definiuje koncepcję strategicznej karty wyników jako system umożliwiający odejście od jednostronnego ukierunkowania tradycyjnych systemów zarządzania przedsiębiorstwem, czyli ich zorientowania jedynie na osiągnięcie wyników finansowych, na rzecz kompleksowego systemu zarządzania bazującego na syntetycznych systemach mierników ilościowych i jakościowych, będącego odzwierciedleniem strategii (Hofman, 2003, s. 39).

Zatem BSC jest systemem zarządzania umożliwiającym implementację strategii na wszystkich poziomach. Po skonstruowaniu karty na poziomie korporacyjnym jest ona kaskadowana w dół dla strategicznych jednostek biznesowych oraz działów wsparcia (Niven, 2006, s. 318). Pełne wdrożenie modelu BSC wymaga kaskadowania karty korporacyjnej aż do poziomu indywidualnej jednostki. Dla każdego środka precyzowane są indywidualne cele oraz mierniki umożliwiające precyzyjną ich realizację oraz pomiar ich efektów. Harmonizacja tych działań pozwala przy tym na osiągnięcie efektów synergii. Analogicznie sytuacja ma się w zakresie formułowania celów i pomiaru w obszarze innowacji, co w efekcie umożliwia integrację planowania rozwoju ze strategią biznesową (Kaplan, Norton, 2010, s. 87-110).

Wykorzystanie metodologii Balanced Scorecard do pomiaru potencjału rozwoju innowacyjności przedsiębiorstwa oraz jej wdrożenia jest możliwe dzięki temu, jak podchodzi ona do procesu kreowania wartości w przedsiębiorstwie. Bazuje ona na wzajemnym oddziaływaniu czterech perspektyw postrzegania zachodzących zmian (Litwa, 2010, s. 91):

- zmian postaw pracowników, 
- zmian wewnętrznej kultury organizacji,

- zmiany postaw klientów,

- zmiany podejścia do efektów działania przedsiębiorstwa.

Punktem wyjścia budowania wartości przedsiębiorstwa jest implementacja nowej filozofii funkcjonowania. Jej podstawą jest doprowadzenie do zmiany podejścia pracowników poprzez działania zwiększające ich poziom kompetencji zawodowych oraz satysfakcji z pracy, co w efekcie skutkuje wzrostem ich motywacji, tworząc w ten sposób wewnętrzną kulturę organizacji nastawioną na rozwój i wdrażanie rozwiązań innowacyjnych. W rezultacie poprawy procesów wewnętrznych przedsiębiorstwo jest w stanie opracować i zaoferować klientom produkty dostarczające im większej wartości, spełniające oczekiwania w zakresie jakości, użyteczności oraz dostępności, w tym również pod względem cenowym, co z kolei skutkuje zwiększeniem przychodów. W efekcie zwiększonej sprzedaży przedsiębiorstwo jest w stanie wygenerować zwiększone zyski, co skutkuje wzrostem jego wartości. Równocześnie zapewnia sobie w ten sposób zwiększone środki na sfinansowanie kolejnych inwestycji w obszarze innowacyjności.

Zatem efekty wdrożenia filozofii BSC stwarzają bardzo znaczące i atrakcyjne możliwości, do których można zaliczyć (Kaplan, Norton, 1996, s. 132):

1. System wskaźników zawarty w ramach BSC umożliwia ciągłą kontrolę i monitorowanie poziomu realizacji celów strategicznych poprzez wykorzystanie różnorodnych wskaźników wydajności, uwzględniających rozmaite aspekty funkcjonowania przedsiębiorstwa. Dzięki temu menedżerowie otrzymują na bieżąco informacje, pozwalające na dynamiczną aktualizację strategii i modyfikacji działań nieefektywnych, umożliwia to efektywne zarządzanie udoskonalaniem procesu, w tym oceny faktycznie osiągniętej efektywności inwestycji. BSC zawiera przegląd struktury przyczynowej firmy, głównych czynników wydajności, ich rozwoju i wzajemnych relacji.

2. BSC umożliwia sprawną komunikację pomiędzy wszystkimi jednostkami organizacyjnymi firmy w czasie wdrożenie strategii oraz wdrożenie systemu informacji zwrotnej, umożliwiając zintegrowanie celów ustalonych dla poszczególnych jednostek organizacyjnych i osób z celami całej firmy.

3. BSC skupia uwagę zarządzających i wszystkich innych pracowników na realizacji strategii, w związku z tym umożliwia tworzenie potencjału 
rozwojowego. Natomiast sprawdzanie zrealizowanych w przeszłości rezultatów stanowi jedynie narzędzie, a nie cel sam w sobie.

Aby dokonać efektywnego pomiaru poziomu innowacyjności przedsiębiorstwa przy wykorzystaniu Balanced Scorecard, należy wyselekcjonować odpowiedni zestaw wskaźników, dzięki któremu będzie możliwa ocena udziału działalności innowacyjnej w łańcuchu wartości przedsiębiorstwa. Jak podkreśla wielu autorów, najlepsze rezultaty w tym zakresie osiągają przedsiębiorstwa, które są w stanie zmierzyć realizację działań innowacyjnych w każdej z wyodrębnionych w ramach BSC płaszczyzn. W tym celu konieczny jest wybór odpowiednich dedykowanych wskaźników. W tabeli 1 zestawiono przykładowe wskaźniki wykorzystywane przez przedsiębiorstwa do pomiaru działań innowacyjnych.

Tabela 1. Przykładowe mierniki wykorzystywane do pomiaru stopnia innowacyjności

\begin{tabular}{|r|l|}
\hline Lp. & \multicolumn{1}{|c|}{ Miernik } \\
\hline 1 & liczba patentów \\
\hline 2 & odsetek sprzedaży nowych produktów wobec sprzedaży ogółem \\
\hline 3 & odsetek sprzedaży produktów chronionych prawem wobec sprzedaży ogółem \\
\hline 4 & czas uruchomienie nowego produktu na rynku w porównaniu z konkurencją \\
\hline 5 & czas uruchomienia nowego produktu w porównaniu z planem \\
\hline 6 & czas potrzebny na opracowanie nowej generacji produktów \\
\hline 7 & rentowność kosztów badawczo-rozwojowych \\
\hline 8 & $\begin{array}{l}\text { poziom kosztów operacyjnych przed opodatkowaniem za dany okres w porównaniu do } \\
\text { całkowitych kosztów rozwoju }\end{array}$ \\
\hline 9 & wskaźnik ilości zgłoszonych nowych pomysłów na 100 zatrudnionych \\
\hline 10 & poziom wydatków na szkolenia \\
\hline 11 & wskaźnik rotacji zatrudnienia \\
\hline 12 & poziom nakładów na nowe technologie \\
\hline 13 & zagregowana wartość ROI z innowacyjnych produktów \\
\hline 14 & liczba nowych pomysłów/usprawnień zaproponowanych przez pracowników \\
\hline 15 & wielkość nakładów na R\&D \\
\hline
\end{tabular}

Źródło: opracowanie własne.

Zaprezentowane w tabeli 1 mierniki zostały wybrane przez autora spośród 80 miar zawartych w badaniu ankietowym dotyczącym ustalenia najczęściej stosowanych w przedsiębiorstwach wskaźników służących pomiarowi stopnia realizacji celów w ramach poszczególnych płaszczyzn BSC (zaprezentowano jedynie miary 
służące do pomiaru stopnia innowacyjności, zostały one wybrane spośród wielu innych mierników badających inne aspekty funkcjonowania przedsiębiorstwa). Wzmiankowane miary zostały wskazane przez menedżerów w badaniach ankietowych przeprowadzonych w USA przez Maltza, Shenhara i Reilly'ego (2003) oraz w Polsce przez autora niniejszego artykułu (Litwa, 2010, s. 330-364).

\section{Podsumowanie}

Współczesne przedsiębiorstwa kładą duży nacisk na tworzenie strategii, które zapewniłyby im przewagę konkurencyjną. Jedną z takich ścieżek rozwoju jest strategia inwestowania w zwiększanie poziomu innowacyjności, co dla współczesnych firm wydaje się koniecznością. Należy przy tym pamiętać, że działania innowacyjne niosą ze sobą znaczące ryzyko. Stąd tak istotna jest konieczność dysponowania właściwym systemem pomiaru efektów działań w tym obszarze. Sytuacja ta prowadzi do ustawicznego rozwoju dotychczas stosowanych narzędzi, jak również formułowania nowych koncepcji. W założeniach mają one pozwolić kompleksowo zarządzać efektywnością działania przedsiębiorstwa, budując organizacje elastycznie reagujące na szybkie zmiany otoczenia, bazując na właściwej diagnozie zarówno sytuacji bieżącej, jak i tworzonego potencjału. Jedną z możliwych alternatyw jest wykorzystanie zaprezentowanej w niniejszym artykule koncepcji Balanced Scorecard.

Przydatność BSC do pomiaru efektywności procesu innowacyjnego w przedsiębiorstwie wynika z faktu, że narzędzie to pozwala nie tylko na pomiar w różnych perspektywach wartości dodanej generowanej przez działalność innowacyjną, lecz także na harmonijne wkomponowanie projektów innowacyjnych w strategiczne działania organizacji. Należy jednak zauważyć, że pomiar działalności innowacyjnej jest i zawsze będzie utrudniony z powodu kłopotów z kwantyfikowalnością tego procesu, gdyż wykracza on poza ramy standardowej działalności ze względu na twórczą naturę tego procesu. $Z$ tej przyczyny zbyt doktrynalne podejście do pomiaru efektów i sposobu działania jednostek innowacyjnych może spowodować spadek ich kreatywności. Dlatego efektywność zastosowania BSC będzie uzależniona od umiejętności menedżerów, od właściwego doboru mierników i od jakości systemu informacyjnego organizacji. 


\section{Literatura}

Bassani, C., Lazzarotti, V., Manzini, R., Pellegrini, L., Santomauro, S. (2010). Measuring performance in R\&NPD: the case of Whitehead Alenia Sistemi Subacquei - a Finmeccanica company. European Journal of Innovation Management, 13 (4), 481-506.

Brynjolfsson, E., Yang, S. (1996). Information Technology and Productivity: A Review of the Literature. MIT Sloan School of Management, Advances in Computers, Academic Press, 43, 179-214.

Filipek, T. (2002). Balanced Scorecard w praktyce. Manager, 12, 9-12.

Fink, C.A., Grundler, Ch. (1998). Strategieimplementierung im turbulenten Umfeld. Controlling, 10, 226-237.

Hofman, M. (2003). Balanced Scorecard w Transsystem Łańcut (studium przypadku). Manager, 5, 37-40.

Kaplan, R.S., Norton, P.D. (1996). The balanced scorecard: Translating strategy into action. Boston: Harvard Business School Press.

Kaplan, R.S., Norton, D.P. (2010). Wdrażanie strategii dla osiagnięcia przewagi konkurencyjnej. Warszawa: Wydawnictwa Profesjonalne PWN.

Kerssens van Drongelen, I.C., Bilderbeek, J. (1999). R\&D performance measurement: more than choosing a set of metrics. $R \& D$ Management, 29 (1), 35-46.

Klingebiel, N. (1997). Performance Measurement-Systeme. Das Wirtschaftsstudium, 26 (7), 655-663.

Litwa, P. (2010). Wykorzystanie Strategicznej Karty Wyników w raportowaniu realizacji strategii przedsiębiorstwa. Rozprawa doktorska. Kraków.

Maltz A.C., Shenhar A.J., Reilly R.R. (2003). Beyond the Balanced Scorecard: Refining the Search for Organizational Success Measures. Long Range Planning Journal, 36, 187-204.

Matusiak, K.B. (2011). Innowacje i transfer technologii. Stownik pojęć. Warszawa: PARP.

Neely, A. (2005). The evolution of performance measurement research. Development in the last decade and a research agenda for the next. International Journal of Operations \& Production Management, 25 (12), 1264-1277.

Niven, P.R. (2006). Balanced scorecard step-by-step: Maximizing performance and maintaining results. New York: John Wiley \& Sons.

Płowiec, U. (2010). Refleksje o innowacyjności Polski w perspektywie 2020 roku. Ekonomista, 5, 652-664.

Pomykalski, A. (2001). Innowacje. Łódź: Wydawnictwo Politechniki Łódzkiej. 


\title{
BALANCED SCORECARD USING FOR THE MEASUREMENT THE LEVEL OF THE ENTERPRISE'S INNOVATIVENESS
}

\begin{abstract}
Nowadays, the enterprises are under intense pressure to innovation, which is one of the basic conditions for a competitive advantage. Only enterprises able to introduce innovative changes can efficiently and effectively operate on the market. Innovations give them an opportunity to increase the scale of production and sales, reduce costs or improve the quality of manufactured goods and services etc. The efficiency of innovation management process requires the continuous decision tools development and the application of the principle that "You cannot manage what you cannot measure."

For that reason, the main goal of this article is to present the possibility of using the balanced scorecard (BSC), as a comprehensive performance measurement method the level of innovation of enterprises.
\end{abstract}

Keywords: Balanced Scorecard, a comprehensive performance measurement method, innovation

JEL code: O32 